\title{
FLORAL INDUCTION, PRODUCTION AND SEED QUALITY OF PARSLEY CULTIVARS AS INFLUENCED BY PLANTS VERNALIZATION PERIODS
}

\author{
INDUÇÃO FLORAL, PRODUÇÃO E QUALIDADE DE SEMENTES DE \\ CULTIVARES DE SALSA EM FUNÇÃO DE PERÍODOS DE VERNALIZAÇÃO DAS \\ PLANTAS
}

\author{
Cibele Chalita MARTINS ${ }^{1}$; Carla Gomes MACHADO ${ }^{2}$; Mauricio Feis Ganz SANCHES ${ }^{3}$; \\ Juliana Faria dos SANTOS ${ }^{3}$; Roberval Daiton VIEIRA ${ }^{1}$ \\ 1. Engenheiro agrônomo, Professor, Doutor, Departamento de Produção Vegetal, Faculdade de Ciências Agrárias e Veterinárias - \\ FCAV, Universidade Estadual Paulista - UNESP, Jaboticabal, SP, Brasil. cibele@ fcav.unesp.br; 2. Engenheiro agrônomo, Professor, \\ Doutor, Universidade Federal de Goiás, Campus Jatobá, Jataí, GO, Brasil; 3. Engenheiro agrônomo, Discente do Curso de Pós- \\ graduação em Agronomia, Produção Vegetal, Faculdade de Ciências Agrárias e Veterinárias - FCAV, Universidade Estadual Paulista - \\ UNESP, Jaboticabal, SP, Brasil.
}

\begin{abstract}
In the production of parsley (Petroselinum crispum) seeds is recommended the cultivation in locations of low temperatures to permit the emission of floral stalk. The study aimed to verify the effect of vernalization on floral induction, production and quality of parsley seeds. Ten plants of three cultivars (Caipira, Chacareira and Lisa Grande Portuguesa (O. Enke)) grown in pots for six months were submitted to vernalization at $5{ }^{\circ} \mathrm{C}$ for $0,15,30$ and 45 days. After treatment, the plants were transferred to greenhouse and evaluated for period and flowering percentage, seed yield per plant and seed quality. The seed quality was evaluated by weight of a thousand seeds, germination (percentages of normal and abnormal seedlings, dormant and dead seeds), first count of germination, accelerated aging, dormancy after accelerated aging, seedling emergence in the field and seed water content before and after accelerated aging. It was concluded that the vernalization does not promotes floral induction and production of parsley seeds. For Lisa Grande Portuguesa (O. Enke) cultivar, the vernalization of the plant for 30 days enables the production of seed with high germination and vigor. Parsley seeds dormancy can be caused by plants vernalization periods between 30 and 45 days depending on the cultivar, followed by the exposure of the seeds to the conditions of high temperature and relative humidity of the air $\left(41^{\circ} \mathrm{C} / 100 \%\right.$, UR/72 h).
\end{abstract}

KEYWORDS: Petroselinum crispum. Flowering. Dormancy. Vigor. Vegetables.

\section{INTRODUCTION}

Parsley [Petroselinum crispum (Mill.) Nyman ex A.W. Hill] is a biennial herbaceous plant that can be also grown as an annual crop. It is originated from Europe and cultivated in Brazil for more than 300 years. It is one of the most popular plants in the world gastronomy, its leaves being consumed either fresh or dehydrated. Its culm is erect, reaching a height between 15 and $30 \mathrm{~cm}$. Parsley regenerates easily and consequently, enables various harvest during the year (FILGUEIRA, 2003).

Parsley plants grow better under warm temperatures and are damaged by extreme temperatures, both high and low. It can be sown during the whole year in the South of Brazil, in São Paulo and Minas Gerais states. In other Brazilian states and regions, sowing should take place between February and November. For the production of seeds, the recommendation is to grow the plants in low altitude and low temperature sites to induce the emission of the flower rachis (FILGUEIRA, 2003; TRINCA, 2007).
The floral induction process consists of the transformation of the vegetative bud into reproductive or floral bud under a stimulus from the environment; if this stimulus does not take place, there will be no fruit and seed production (NASCIMENTO, 2005; MARCOS-FILHO, 2005). But, to respond to the stimulus, the biennial species should surpass the juvenile period and exhibit a certain vegetative growth which is genotype dependent since the buds and meristem tissue are the receptors of those stimuli (MARCOS-FILHO, 2005; ALESSANDRO; GALMARINI, 2007).

Some vegetable crops demand low temperatures for the induction of flowering and, consequently, the production of seeds, such as are the cases of onion, carrot, and cauli-flower. These are conditions which can be artificially provided to the plants in cold chambers in a process named vernalization.

The temperature range that brings about floral induction depends on genetics characteristics and, for most of the vegetable crops, it is between 5 and $10{ }^{\circ} \mathrm{C}$ (FILGUEIRA, 2003; MARCOS-FILHO, 2005; ALESSANDRO; GALMARINI, 2007; 
VERDIAL et al., 2007). But no research information concerned to the effects of vernalization on parsley seed production were found.

So, the objective of this research was to verify the effects of plant vernalization on the floral induction, production and quality of parsley seeds.

\section{MATERIAL AND METHODS}

The experiment was carried out on the São Manuel Experimental Farm and in the Seed Analysis Laboratory of the Faculty of Agronomic Sciences at UNESP, São Paulo State, Brazil (2244'50" S, 48 $34^{\circ} 00^{\prime \prime} \mathrm{W}$; altitude $765 \mathrm{~m}$; climate $\mathrm{Cwa}$, hot temperature in general, with rains in the summer and drought in the winter (CUNHA; MARTINS, 2009)). Monthly temperatures minimum, maximum and mean during the experiment are shown in Table 1.

Parsley seeds of the cultivars Caipira, Chacareira, and Lisa Grande Portuguesa (O. Enke) were sown in September of 2008 in $1.5 \mathrm{~L}$ vases which were filled with a mixture in equal proportions of soil, sand, and Plantmax ${ }^{\circledR}$ and the plantlets grown under greenhouse conditions. Plants remained for six months in these conditions so that there was sufficient vegetative growth to become sensitive to vernalization process (SAMUOLIENE et al., 2009).

Table 1. Monthly minimum, maximum and mean temperatures $\left({ }^{\circ} \mathrm{C}\right)$ measured during the months of the experiment. São Manuel, São Paulo State, Brazil.

\begin{tabular}{lccc}
\hline \multirow{2}{*}{ Month and year } & \multicolumn{3}{c}{ Temperature $\left({ }^{\circ} \mathbf{C}\right)$} \\
\cline { 2 - 4 } & Minimum & Maximum & Mean \\
\hline September 2008 & 13.8 & 26.5 & 20.1 \\
October 2008 & 14.2 & 27.8 & 21.0 \\
November 2008 & 17.3 & 30.4 & 23.9 \\
December 2008 & 16.9 & 29.4 & 22.9 \\
January 2009 & 15.1 & 29.1 & 21.9 \\
February 2009 & 17.4 & 29.8 & 23.4 \\
March 2009 & 16.7 & 29.4 & 22.7 \\
April 2009 & 14.1 & 27.8 & 20.9 \\
May 2009 & 12.2 & 25.7 & 19.0 \\
June 2009 & 8.7 & 22.9 & 15.8 \\
July 2009 & 10.9 & 22.9 & 16.9 \\
August 2009 & 11.4 & 26.1 & 18.8 \\
September 2009 & 12.7 & 25.2 & 18.9 \\
\hline
\end{tabular}

After this period (end of March of 2009), for each cultivar and at 15 day intervals, 10 vases with one plant per vase were transferred to a cold chamber $\left(5^{\circ} \mathrm{C}\right)$ making a total of 90 vases with a maximum permanence period of 45 days. So, the treatments analyzed in this experiment were four vernalization periods $(0,15,30$, and 45 days $)$ and three cultivars (Caipira, Chacareira and Lisa Grande Portuguesa). At the end of the vernalization procedure (May 15 ${ }^{\text {th }}, 2009$ ), all the vases were transferred to a greenhouse, for the following evaluations:

\section{Flowering and seed production}

The percentage of plants emitting floral rachises and the moment it took place. Among the plants submitted to vernalization, eight were randomly taken and their seed production evaluated. Seeds were harvested, cleaned, weighed and the results expressed in $\mathrm{g}$ of seeds per plant.
In the laboratory, the seeds of each treatment were homogenized and submitted to the following determinations and tests:

\section{One thousand seeds weight}

It was determined with basis on eight 100 seed samples randomly taken from the seeds. The samples were weighed and the results expressed in $g$ (BRASIL, 2009).

\section{Germination test}

This test was carried out with four 50 seed samples. The seeds were spread on top of two filter paper which were wet with an amount of water equal to 2.5 times the weight of the paper in $11 \times 11$ $\times 3.5 \mathrm{~cm}$ transparent plastic boxes. The boxes were placed in a germination chamber at $20{ }^{\circ} \mathrm{C}$ with counting taking place 10 and 28 days after sowing. Percentage of normal and abnormal seedlings were determined (BRASIL, 2009). 


\section{First count of germination}

This was the percentage of normal seedlings counted on the $10^{\text {th }}$ day after the beginning of the germination test (BRASIL, 2009).

\section{Accelerated aging test}

We carried out with $2 \mathrm{~g}$ of seeds spread on top of a screen in a transparent plastic box $(11 \times 11$ $\times 3.5 \mathrm{~cm})$ to which $40 \mathrm{~mL}$ of water was added and kept at $41{ }^{\circ} \mathrm{C}(100 \%)$ for 72 hours (RODO et al., 2000). Then, the seeds were submitted to the standard germination test and the resulting seedlings evaluated on the $10^{\text {th }}$ day.

\section{Tetrazolium test}

It was executed after germination and accelerated aging tests, using the remaining seeds from each one. Seeds were longitudinally and medially sectioned through the embryo. One of the halves of each seed was immersed in a $0.1 \%$ tetrazolium solution and kept in a dark chamber at $35{ }^{\circ} \mathrm{C}$ for a period of 60 minutes. After that period, the seeds were washed and the evaluation made immediately after and the seeds were classified as either dormant (after germination and accelerated aging tests) or dead (after germination test) (ANDRADE et al., 1996).

\section{Seed water content}

Seed water content was determined before and after the seeds were artificially aged using two samples per lot by the oven method with high temperature for a short period of exposition, that is, $130 \pm 3{ }^{\circ} \mathrm{C} / 1$ hour (BRASIL, 2009).

\section{Seedling emergence in the field}

Four replications of 100 seeds were sown in $0.8 \mathrm{~m}$ long and $1.0 \mathrm{~cm}$ deep rows. The distance between rows was of $10 \mathrm{~cm}$. During the test duration, when necessary, irrigations were made at the end of the day. Seedling counts were made 40 days after sowing with the results being presented in percentage (VIEIRA and CARVALHO, 1994).

\section{Statistical procedures}

A completely random design with eight repetitions for seed production and 1000 seeds weight and four repetitions for the other determinations was adopted. The treatments were arranged in a $4 \times 3$ factorial scheme in which 4 were the vernalization periods and 3 the cultivars. Means were compared with the Tukey test at the level of $5 \%$ of probability.

\section{RESULTS AND DISCUSSION}

The beginning of the floral rachis emission occurred one year after sowing (approximately four months after vernalization) and 90 to $100 \%$ of the plants flowered, regardless of cultivar and vernalization treatments. Alessandro and Galmarini (2007) and Verdial et al. (2007) reported results with carrot and strawberry in which floral induction was caused by vernalization depending on cultivar and time of exposition to low temperatures.

For parsley, probably the flowering stimulus may be caused by other factors such as, perhaps, the photoperiod or this factor in association with low temperatures such as reported for some carrot and lettuce cultivars and beetroot (NASCIMENTO, 2005). At the time of the year in which flower rachises started to be emitted, day length in São Manuel was of approximately 11 hours and 50 minutes and temperature conditions are in Table 1.

Seed production by the evaluated cultivars was not affected by vernalization with the exception of the Caipira cultivar which yielded less than the Chacareira cultivar when vernalization period was of 45 days (Table 2).

Vernalization had no effect on the translocation and accumulation of seed reserves and thus on seed mass as shown by the determination of the mass of 1,000 seeds. Lisa Grande Portuguesa parsley produced seeds lighter than those of the Caipira but similar to those of the Chacareira cultivar. Chacareira seeds are of intermediate weight, not different from that of the Caipira cultivar under some environmental conditions, such as when vernalization is not applied or when this treatment lasts for 30 days (Table 2). In this way, seeds of different cultivars exhibited different masses since this is a genetically determined characteristic (BRASIL, 2009). Same behavior was verified for carrot seeds progenies, species belonging to the family Apiaceae, as parsley (MARTINS et al., 2014).

The one thousand seed mass is usually used to calculate sowing density and the number of seeds per package and since it is genetically determined, that is, it depends on the cultivar, its information is not demanded by the Ministry of Agriculture for the commerce of Vegetable seed lots (BRASIL, 1986; BRASIL, 2009).

Taking in consideration that seed production per plant was similar but the weight of the Lisa Grande Portuguesa cultivar seeds was lower, it may concluded that that cultivar produces a larger number of seeds, which are lighter than the seeds of the other cultivars. 
Table 2. Seed production, one thousand seed weight, first count of germination test, germination, abnormal seedlings, dormant and dead seeds, accelerated aging test, dormancy after accelerated aging, seedling emergence in the field, seed initial and after accelerated aging moisture content of parsley seeds of the cultivars Lisa Grande Portuguesa, Caipira, and Chacareira produced by plants vernalized for 0, 15, 30, and 45 days at a temperature of $5{ }^{\circ} \mathrm{C}$. São Manuel, state of São Paulo, Brazil. 2013.

\begin{tabular}{|c|c|c|c|c|c|c|}
\hline \multirow{2}{*}{$\begin{array}{c}\text { Vernalization } \\
\text { (days) }\end{array}$} & $\begin{array}{c}\text { Lisa Grande } \\
\text { Portuguesa }\end{array}$ & Caipira & Chacareira & $\begin{array}{l}\text { Lisa Grande } \\
\text { Portuguesa }\end{array}$ & Caipira & Chacareira \\
\hline & \multicolumn{3}{|c|}{ Seed production (g/plants) } & \multicolumn{3}{|c|}{1,000 seeds mass $(\mathrm{g})$} \\
\hline 0 & $69.48 \mathrm{~A} \mathrm{a}$ & $85.90 \mathrm{Aa}$ & $82.40 \mathrm{Aa}$ & $1.50 \mathrm{Ba}$ & $1.97 \mathrm{Aa}$ & $1.73 \mathrm{ABa}$ \\
\hline 15 & $82.00 \mathrm{~A} \mathrm{a}$ & $71.08 \mathrm{Aa}$ & $69.58 \mathrm{Aa}$ & $1.49 \mathrm{Ba}$ & $1.96 \mathrm{Aa}$ & $1.64 \mathrm{~B} \mathrm{a}$ \\
\hline 30 & $78.53 \mathrm{~A} \mathrm{a}$ & $83.35 \mathrm{Aa}$ & $87.50 \mathrm{Aa}$ & $1.52 \mathrm{Ba}$ & $1.93 \mathrm{Aa}$ & $1.75 \mathrm{ABa}$ \\
\hline 45 & $77.80 \mathrm{ABa}$ & $69.29 \mathrm{Ba}$ & $98.25 \mathrm{Aa}$ & $1.54 \mathrm{Ba}$ & $1.95 \mathrm{Aa}$ & $1.69 \mathrm{~B} \mathrm{a}$ \\
\hline \multirow[t]{2}{*}{$\mathrm{CV} \%$} & \multicolumn{3}{|c|}{28.10} & \multicolumn{3}{|c|}{11.85} \\
\hline & \multicolumn{3}{|c|}{ First count of germination (\%) } & \multicolumn{3}{|c|}{ Germination (\%) } \\
\hline 0 & $46.5 \mathrm{Bc}$ & $91.5 \mathrm{Aa}$ & $86.5 \mathrm{Aa}$ & $51.0 \mathrm{Bc}$ & $93.0 \mathrm{Aa}$ & $88.0 \mathrm{Aa}$ \\
\hline 15 & $51.0 \mathrm{Bbc}$ & $83.0 \mathrm{Aa}$ & $88.0 \mathrm{Aa}$ & $60.0 \mathrm{Bb}$ & 84.0 Ab & $90.5 \mathrm{Aa}$ \\
\hline 30 & $61.5 \mathrm{Bab}$ & $93.0 \mathrm{Aa}$ & $91.0 \mathrm{Aa}$ & $89.0 \mathrm{Aa}$ & $96.0 \mathrm{Aa}$ & $95.5 \mathrm{Aa}$ \\
\hline 45 & $63.5 \mathrm{Ba}$ & 86.0 Aa & $90.5 \mathrm{Aa}$ & $66.0 \mathrm{Bb}$ & 88.0 Aab & $91.5 \mathrm{Aa}$ \\
\hline \multirow[t]{2}{*}{$\mathrm{CV} \%$} & \multicolumn{3}{|c|}{8.04} & \multicolumn{3}{|c|}{5.53} \\
\hline & \multicolumn{3}{|c|}{ Abnormal seedlings (\%) } & \multicolumn{3}{|c|}{ Dormant $(\%)$} \\
\hline 0 & 0.0 & 1.5 & 1.5 & $1.0 \mathrm{Ba}$ & $1.5 \mathrm{Bb}$ & $6.0 \mathrm{Aa}$ \\
\hline 15 & 0.0 & 0.0 & 1.5 & $0.0 \mathrm{Aa}$ & $1.5 \mathrm{Ab}$ & $1.5 \mathrm{Aab}$ \\
\hline 30 & 1.5 & 1.0 & 0.5 & $0.0 \mathrm{Aa}$ & $2.5 \mathrm{Aab}$ & $1.5 \mathrm{Aab}$ \\
\hline 45 & 0.0 & 0.0 & 1.0 & 3.0 Aba & $7.0 \mathrm{Aa}$ & $0.5 \mathrm{Bb}$ \\
\hline \multirow[t]{2}{*}{$\mathrm{CV} \%$} & \multicolumn{3}{|c|}{186.76} & \multicolumn{3}{|c|}{118.67} \\
\hline & \multicolumn{3}{|c|}{ Dead seeds (\%) } & \multicolumn{3}{|c|}{ Accelerated Aging Test - AA (\%) } \\
\hline 0 & $48.0 \mathrm{Aa}$ & $4.0 \mathrm{Bb}$ & $4.5 \mathrm{~B} \mathrm{a}$ & $37.0 \mathrm{Ca}$ & $92.0 \mathrm{Aa}$ & $77.5 \mathrm{Ba}$ \\
\hline 15 & $40.0 \mathrm{Aa}$ & $14.5 \mathrm{Ba}$ & $6.5 \mathrm{C} \mathrm{a}$ & $36.5 \mathrm{Ba}$ & 81.5 Aab & $91.0 \mathrm{Aa}$ \\
\hline 30 & $9.5 \mathrm{Ac}$ & $0.5 \mathrm{Bb}$ & $2.5 \mathrm{ABa}$ & $43.0 \mathrm{Ba}$ & $74.5 \mathrm{Ab}$ & $82.5 \mathrm{Aa}$ \\
\hline 45 & $31.0 \mathrm{Ab}$ & $5.0 \mathrm{Bb}$ & $7.0 \mathrm{~B} \mathrm{a}$ & $35.0 \mathrm{Ca}$ & $56.5 \mathrm{Bc}$ & $80.0 \mathrm{Aa}$ \\
\hline \multirow[t]{2}{*}{$\mathrm{CV} \%$} & \multicolumn{3}{|c|}{30.17} & \multicolumn{3}{|c|}{12.76} \\
\hline & \multicolumn{3}{|c|}{ Dormancy after AA $(\%)$} & \multicolumn{3}{|c|}{ Seedling emergence in the field $(\%)$} \\
\hline 0 & $4.0 \mathrm{Ab}$ & $0.0 \mathrm{Ab}$ & $0.0 \mathrm{Ab}$ & $40.3 \mathrm{Bc}$ & $82.5 \mathrm{Aab}$ & $80.5 \mathrm{Aa}$ \\
\hline 15 & $0.0 \mathrm{Ab}$ & $4.5 \mathrm{Ab}$ & $0.0 \mathrm{Ab}$ & $43.5 \mathrm{Bbc}$ & $77.0 \mathrm{Aab}$ & $84.3 \mathrm{Aa}$ \\
\hline 30 & $42.0 \mathrm{Aa}$ & $17.5 \mathrm{Ba}$ & $0.0 \mathrm{Cb}$ & $58.3 \mathrm{Ba}$ & $83.0 \mathrm{Aa}$ & $83.3 \mathrm{Aa}$ \\
\hline 45 & $0.0 \mathrm{Bb}$ & $0.0 \mathrm{Bb}$ & $15.5 \mathrm{Aa}$ & $50.3 \mathrm{Bab}$ & $73.0 \mathrm{Ab}$ & $80.8 \mathrm{Aa}$ \\
\hline \multirow[t]{2}{*}{$\mathrm{CV} \%$} & \multicolumn{3}{|c|}{68.13} & \multicolumn{3}{|c|}{7.31} \\
\hline & \multicolumn{3}{|c|}{ Initial seed water content $(\%)$} & Seed wate & content a & $\mathbf{A A}(\%)$ \\
\hline 0 & 7.0 & 6.3 & 6.7 & 28.8 & 33.9 & 28.0 \\
\hline 15 & 7.1 & 6.6 & 6.4 & 32.7 & 37.5 & 29.0 \\
\hline 30 & 6.6 & 6.4 & 6.4 & 37.2 & 34.1 & 28.6 \\
\hline 45 & 7.0 & 6.1 & 6.7 & 32.4 & 24.2 & 36.7 \\
\hline CV\% & & 0.93 & & & 5. & \\
\hline
\end{tabular}

Means in the same column, followed by the same small letter, and in the same line, by the same capital letter, are not statistically different at the level of $5 \%$ of probability according to the Tukey test $(\mathrm{P}<0.05)$. CV\%: Coefficient of Variation.

The lower weight of the seeds seems to have hampered the seeds physiological quality, since the Lisa Grande Portuguesa cultivar, as a general result, showed the highest proportions of dead seeds and also was the one displaying the lowest vigor, according to results of the first count of germination, accelerated aging, seedling emergence in the field, and germination tests (Table 2).
In a similar way, it was found that carrot seeds of greater sizes exhibited the highest physiological potential since they had larger storage tissues, unlike smaller seeds, which tended to low germination results and low vigor seedlings (SANTOS et al., 2010; MARTINS et al., 2013).

However, after 30 days of vernalization, seeds of Lisa Grande Portuguesa cultivar showed 
highest germination percentage, similar to the other cultivars, and lower percentage of dead seeds (Table 2). This phenomenon is caused by metabolic adaptations of biannual species of temperate climate for the survival and perpetuation of the species under ecological conditions of freezing winters and springs with mild temperatures, as simulated by vernalization (NASCIMENTO; GUEDES, 1988; MARTINS et al., 2013)

Cultivars and vernalization periods did not affect the percentage of abnormal seedlings, which were relatively low (between 0.0 and 1.5\%), indicating that the treatments had no influence on this characteristic.

Vigor level of the parsley seeds of the Lisa Grande Portuguesa cultivar, as evaluated by the first count of germination and seedling emergence in the field tests, was favorably influenced by the vernalization treatment of the plants for 30 and 45 days. Particularly the vernalization period of 30 days also resulted in the production of seeds of the highest germination with the lowest percentage of dead seeds and these results were significantly better than the others.

The accelerated aging test did not detect significant differences in the vigor of seeds of the Lisa Grande Portuguesa and Chacareira cultivars ascribable to vernalization. Though the seeds of the Caipira cultivars produced under conditions of vernalization for 30 and 45 days were of lower vigor, these results should be interpreted carefully since they were not confirmed by the other vigor tests. The results obtained for 30 days of vernalization could be ascribed to seed dormancy imposed to the seeds by the high temperature and relative humidity values characteristics of the accelerated aging procedure.

In this research, when the accelerated aging test results were being evaluated, a high proportion of non-germinated seeds seemed not to have imbibed water. Thus a decision of keeping those seeds in the moist substratum for 28 days was made; that number of days would be the date of the final count in a standard germination test, followed by the procedure of submitting those firm, non-germinated, seeds to the tetrazolium test, to verify if their non germinability was due to their being dormant or dead.

This procedure allowed to verify that the seeds of the Lisa Grande Portuguesa, Caipira and Chacareira cultivars resulting from the vernalization treatments of 30, 30, and 45 days, showed, after accelerated aging, dormancy proportions of 42,18 , and $16 \%$, respectively. It also permitted to verify that the plants of some parsley cultivars, submitted to $5{ }^{\circ} \mathrm{C}$ for periods between 30 and 45 days, produce seeds that may show dormancy, if submitted to high temperature and relative humidity values (provided, in this research work, by the conditions of the accelerated aging test).

As observed in this research, extreme conditions of temperature have been reported to be able to bring about dormancy in seeds as a defense mechanism to preserve seed viability under adverse conditions (MARCOS-FILHO, 2005; VIVIAN et al., 2008; OLIVEIRA et al., 2011; CARVALHO; NAKAGAWA, 2012).

This is an important information for parsley seeds, since factors associated with the occurrence of dormancy in parsley seeds have not been clarified and the dormancy of those seeds is a common problem for the production of this species, causing tardiness and low uniformity in seedling emergence (TRINCA, 2007).

Caipira cultivar seeds production was hampered by the vernalization treatment for 15 days since they presented lower germination and higher proportion of dead seeds, probably due to genetic factors for ecological adaptation (MARTINS et al., 2013). On the other hand, this deleterious effect was not verified when seed vigor was determined by the first count of germination and seedling emergence in the field tests.

For the Caipira cultivar the vernalization periods did not promote the production of seeds with germination speed (first count of germination test) and percentage of seedling emergence in the field different from the non-vernalized plants, thus indicating that the vernalization of the plants of that cultivar is not justifiable.

There are studies on genetic breeding and vernalization of carrot seed that verified different responses among genotypes for temperatures and periods of vernalization on the viability, vigor and seed germination (NASCIMENTO; GUEDES, 1988; MARTINS et al., 2013; MARTINS et al., 2014).

Among the evaluated cultivars, Chacareira was the least influenced by vernalization as to seeds physiological quality since, among the evaluated characteristics, only the rate of dormancy before and after the accelerated aging treatment were affected. Increasing periods of vernalization induced secondary dormancy in response to cold in Caipira cultivar seeds, with higher production of dormant seeds before the accelerated aging test. The opposite effect was observed for the Chacareira seeds while the Lisa Grande Portuguesa cultivar was not influenced by that factor. These differences between cultivars are related to genetic causes and variables 
responses to environmental stimuli (CARVALHO; NAKAGAWA, 2012; MARTINS et al., 2014).

The initial parsley seed water content was between 6.1 and $7.1 \%$. This difference, from a biological point-of-view, is considered nonsignificant, thus allowing to conclude that the tests results were not affected by differences in metabolic activity, the speed of moistening and seed deterioration due to the initial seed moisture. Recommendation is made that differences in seed moisture content before the aging of seed samples are not larger than 2 percentage points (MARCOSFILHO, 2005).

For the comparison of one thousand seeds weight, seed water content should also be approximately the same for the different samples
(BRASIL, 2009). These similar and relatively low moisture contents may be attributed to the low relative humidity of the air at the harvesting period and the period previous to the tests run to evaluate seed quality.

\section{CONCLUSIONS}

Parsley seed production and floral induction are not affected by vernalization process, however, it promotes changes on seed quality.

Parsley seeds dormancy may be induced by the vernalization of the plants for periods of 30 to 45 days, depending on cultivar, when followed by the submission of the seeds to adverse conditions (high temperature and relative humidity).

RESUMO: Na produção de sementes de salsa (Petroselinum crispum) recomenda-se o cultivo em locais de baixas temperaturas para possibilitar a emissão do pendão floral. O objetivo do trabalho foi verificar o efeito da vernalização $(0,15,30$ e 45 dias) na indução floral, produção e qualidade de sementes de salsa. Dez plantas de três cultivares (Caipira, Chacareira e Lisa Grande Portuguesa (O. Enke)) cultivadas em vasos por seis meses, foram submetidas à vernalização a $5{ }^{\circ} \mathrm{C}$ por $0,15,30$ e 45 dias. Após o tratamento, foram transferidas para casa-de-vegetação e avaliadas quanto à época e porcentagem de florescimento, produção de sementes por planta e qualidade das sementes. A qualidade foi avaliada por meio da determinação da massa de mil sementes, teste de germinação (porcentagens de plântulas normais, anormais, sementes dormentes e mortas), primeira contagem de germinação, teste do envelhecimento acelerado, dormência após o envelhecimento acelerado, emergência de plântulas em campo, teor de água das sementes antes e após o envelhecimento acelerado. Concluiu-se que a vernalização não promoveu a indução floral e a produção de sementes. Para a cultivar Lisa Grande Portuguesa (O. Enke), a vernalização da planta por 30 dias possibilitou a produção de sementes com maior germinação e vigor. A dormência das sementes pode ser causada pela vernalização das plantas por períodos entre 30 e 45 dias, dependendo da cultivar, seguida de exposição das sementes produzidas a condições de altas temperaturas e umidade relativa $\left(41^{\circ} \mathrm{C} / 100 \% \mathrm{UR} / 72 \mathrm{~h}\right)$.

PALAVRAS-CHAVE: Petroselinum crispum. Florescimento. Dormência. Vigor. Hortaliças.

\section{REFERENCES}

ALESSANDRO, M. S.; GALMARINI, C. R. Inheritance of vernalization requirement in carrot. Journal of the American Society for Horticultural Science, Alexandria, v. 132, p. 525-529, 2007.

ANDRADE, R. N. B; SANTOS, D. S. B.; SANTOS-FILHO, B. G.; MELLO, V. D. C. Testes de germinação e de tetrazólio em sementes de cenoura armazenadas por diferentes períodos. Revista Brasileira de Sementes, Brasília, v. 18, n. 1, p. 108-116, 1996. http://dx.doi.org/10.17801/0101-3122/rbs.v18n1p108-116

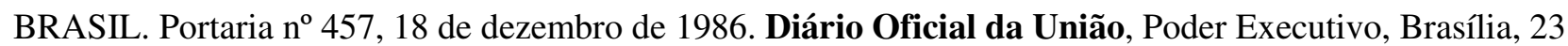
dez., p. 19653. 1986.

BRASIL. Ministério da Agricultura, Pecuária e Abastecimento. Regras para análise de sementes. Secretaria de Defesa Agropecuária. Brasília: MAPA/ACS, 2009. 395p.

CARVALHO, N. M.; NAKAGAWA, J. Sementes: ciência, tecnologia e produção. 5.ed. Jaboticabal: FUNEP. 2012. 590p.

CUNHA, A. R.; MARTINS, D. Classificação climática para os municípios de Botucatu e São Manuel, SP. Irriga, Botucatu, v. 14, n. 1, p. 1-11, 2009. 
FILGUEIRA, F. A. R. Novo manual de olericultura: agrotecnologia moderna na produção e comercialização de hortaliças. 2ed. Viçosa: UFV. 2003. 412p.

MARCOS-FILHO, J. Fisiologia de sementes de plantas cultivadas. Piracicaba: FEALQ. 2005. 495p.

MARTINS, C. C., SILVA, N., MACHADO, C. G. Carrot seed size and progenies influence on seed physiological quality and plant productivity performance. International Journal of Food, Agriculture and Environment, Finland, v. 11, n. 3/4, p. 1143 - 1147, 2013

MARTINS, C. C., SILVA, N., MACHADO, C. G. Testes para a seleção de populações de cenoura visando ao vigor e à longevidade das sementes. Ciência Rural, Santa Maria, v. 44, n. 5, p. 768-775, 2014. http://dx.doi.org/10.1590/S0103-84782014005000001

NASCIMENTO, W. M. Produção de sementes de hortaliças para a agricultura familiar. Brasília, DF: Embrapa Hortaliças. 2005. 15p. (Embrapa Hortaliças. Circular Técnica, 35).

NASCIMENTO, W. M.; GUEDES, A. C. Efeito do tempo de frigorificação das raízes na produção e qualidade de sementes de cenoura, cv. Brasília. Horticultura Brasileira, Brasília, v. 6, n. 2, p. 7-9, 1988.

OLIVEIRA, J. A.; SILVA, T. T. A.; VON-PINHO, E. V. R.; ABREU, L. A. S. Secagem e armazenamento de sementes de sorgo com alto e baixo teor de tanino. Revista Brasileira de Sementes, Londrina, v. 33, n. 4, p. 699-710, 2011. http://dx.doi.org/10.1590/S0101-31222011000400012

RODO, A. B.; PANOBIANCO, M.; MARCOS-FILHO, J. Metodologia alternativa do teste de envelhecimento acelerado para sementes de cenoura. Scientia Agrícola, Piracicaba, v. 57, n. 2, p. 289-292, 2000. http://dx.doi.org/10.1590/s0103-90162000000200015

SAMUOLIENĖ, G.; DUCHOVSKIS, P.; URBONAVICIŪTĖ, A.; SABAJEVIENĖ, G. Flowering initiation in plants of different Apiaceae species. Zemdirbyste-Agriculture, Lithuania, v. 96, n.3, p. 186-198, 2009.

SANTOS, V. J.; GARCIA, D. C.; LOPES, S. J.; EICHELBERGER, L. Qualidade fisiológica de sementes de cenoura classificadas por tamanho. Ciência Rural, Santa Maria, v. 40, n. 9, p. 1903-1908, 2010.

http://dx.doi.org/10.1590/S0103-84782010000900008

TRINCA, J. R. Produção de sementes de salsa. In: CURSO SOBRE TECNOLOGIA DE PRODUÇÃO DE SEMENTES DE HORTALIÇAS, 7, 2007, Brasília, DF. Anais... Brasília: Embrapa Hortaliças. 2007. 1CD.

VERDIAL, M. F.; TESSARIOLI-NETO, J.; MINAMI, K.; SCARPARE-FILHO, J. A.; CHRISTOFFOLETI, P. J.; SCARPARE, F. V.; BARELA, J. F.; DEL-AGUILA, J. S.; KLUGE, R. A. Vernalização em cinco cultivares de morangueiro. Ciência Rural, Santa Maria, v. 37, n. 4, p. 976-981, 2007. http://dx.doi.org/10.1590/S010384782007000400009

VIEIRA, R. D.; CARVALHO, N. M. Testes de vigor em sementes. Jaboticabal: FUNEP, 1994. 164p.

VIVIAN, R.; SILVA, A. A.; GIMENES, JR., M.; FAGAN, E. B.; RUIZ, S. T.; LABONIA, V. Dormência em sementes de plantas daninhas como mecanismo de sobrevivência: breve revisão. Planta Daninha, Viçosa, v. 26, n. 2, p. 695-706, 2008. http://dx.doi.org/10.1590/s0100-83582008000300026 